\title{
FICTION BORN OF RIVAL IMPULSES: A CONVERSATION WITH WELLS TOWER
}

The stories in Wells Tower's debut collection Everything Ravaged, Everything Burned cover many of the same subjects found in the stories of the great American short fiction writer John Cheever: suburbia, family life, love, coming of age. But unlike Cheever's stories, which begin with the semblance that life is fine but then veer off into despair, Tower's stories start off badly and then meander into something like despair. The characters experience pain, loneliness, isolation, and death not as dramatic events, but rather as small miseries. Even when a situation becomes violent, as it does when Ed gets into a fight and hears "blood [howling] in his ears" in the story "Down Through the Valley," or life seems to be "on fire," as Matthew says in "Retreat," the characters barely break into a sweat. In this, Tower's stories don't recall the despair of Dante's Inferno so much as the quirky anguish of a William Carlos Williams poem.

Tower has received the Plimpton Prize from The Paris Review and was featured in The New Yorker's "2o Under 40" Fiction Issue last summer. Everything Ravaged, Everything Burned received two glowing reviews in The New York Times-one from Edmund White and one from Michiko Kakutani. (Kakutani also chose it as one of the best books of 2009.) Tower visited Iowa City in February 2010 to promote the paperback edition of the collection. He is charming, quirkily handsome, and quite possibly the most self-effacing young man writing today. This interview took place on two occasions-the first after Tower's reading at Prairie Lights bookstore, the second the following day.

Sarah Fay: You revised these stories for eight years. Is that right?

Wells Tower: Something like that. I did such violent revision to the stories that my editor started to worry about me. To some extent the revisions were informed by trying to make the story better, but it did get to a point where I would just keep revising and revising and revising not out of any real editorial intelligence but just because I wanted to be a better writer than I am. My feeling about revision is that we don't really know what our stories are about even after the fifth or sixth draft. It's not until I've got some distance 
from a story that I can look at it and see that there is actually a real emotional problem that the story is hinting at. Then the process of revision is about choosing characters, scenes, moments, and style that will get at that emotion in the most effective way.

SF: You've said you revised the story "Retreat" kamikaze-style.

WT: It was originally published in McSweeney's from the point of view of the younger brother. The younger brother is this smart-ass who is pretty sympathetic, and his older brother is this terrible blowhard. The older brother behaves badly and continues to behave badly and is ultimately punished for his bad behavior by ingesting a possibly lethal bit of rotten moose meat. To me, that seemed like a flat line on the moral complexity curve. When I revised it, I thought it would be such a better story-a more interesting assignment-to try to tell it from the standpoint of the unsympathetic character. So that's what I did.

104 SF: Do you treat all your revisions as "assignments"?

WT: I did similar things with a lot of the stories. Often I didn't look at the first draft when I went back to revise. "Revision" was writing a new story, trying to germinate a new story from the initial bit of inspirational DNA.

SF: In your stories, the emotional climax is often very subtle.

WT: There aren't huge revelations. I don't think people are like that. We plan to be nicer, do more yoga, eat more fiber-we think like that all the time, but we just never follow through. But at certain points in the stories, the character comes up with some idea of who he or she wants to be.

SF: And there aren't any happy endings. In "Encounter," Lucy just leaves the restaurant, but you can tell it's a relief of some kind-her version of fiber and yoga.

WT: For me, that was a happy ending. She finally tells Roger she's not going to put up with it anymore. In these stories, the nirvanas the characters get to experience are pretty low amplitude. My favorite ending is in "Door in Your 
Eye." It's a story about this man in his eighties who's in a wheelchair but has been having a phenomenally fun affair with a much younger woman. His daughter moves him down to New Orleans because she doesn't like the idea that he's got something going with this young woman. He becomes preoccupied with a woman who lives across the street because his daughter has told him that she's a prostitute. He just sits on the porch and obsesses about her. One day, he goes over and pays her a visit, and it turns out that she's not a prostitute. She's actually a drug dealer who is close to his age. They have this pseudo-sexual interaction, but it's more of a sympathetic exchange. In the final moment of the story, he sees his daughter come home, and she's looking for him because he's not on the porch and his wheelchair is empty. He pushes the window up and he waves at her. For me, that may be as good as it gets.

SF: Your stories often feel abrupt. The moment before the epiphany-that's when the story ends. John Cheever's "The Swimmer" was 150 pages. It was moving toward a novel and then he cut it down. Do you work like that?

WT: A satisfying short story is one in which you see the moral momentum or sympathetic momentum swing from one character to another over the course of the story. You think one character is making it right but really it's something awful. Then you think the other character is the "good guy." There are these reversals. And I have a real aversion to stories that end with the pendulum right in the middle. I like a radical swing right at the end. Like the ending of The Graduate. I like endings where people think they want something and they get that thing and then it turns out that that's the wrong thing. That's often how it is for us.

It's interesting what you're saying about Cheever. That seems remarkable to me. Right after I got out of graduate school I was surviving doing magazine work and had great gigs with a few different magazines. I was never forced to write newsy stuff or celebrity profiles. They would just give me a topic, a human subject to go and chase for a while, and I would spend time with truckers, or people who hung out at a horse track, or people who worked at Wal-Mart. Basically, they were character studies, maybe eight to ten thousand words. Because there was no angle and nothing was off-limits for the story, I would have fifty to a hundred thousand words of notes for a ten-thousand-word story. The process of assembling a piece was cold carpen- 
try. I would see a scene that was good and another that was okay, and I would hammer those together. For years, I was trying to do the same thing with fiction. I would write a hundred-fifty-page draft for what was supposed to be a thirty-page short story, but for me fiction has to find its way into a much smaller place. And there has to be a coherence of emotion. Just spinning a bunch of ideas and trying to cook that into something that is meaningful and says something that's important about how people are-that never worked for me. Those always just disintegrated.

SF: Do you start with a kernel then? Ezra Pound said that a poem was an organic form, and one has to let the tree grow.

WT: The best of my stories actually tend to be about the same length, usually between six and ten thousand words. For me, it's so much easier to say, "I will not let this story get bigger than a thousand words. I'm going to try really hard to constrain it." And then you let the story get bigger and weirder, but you still have to control it.

106

SF: You seem to absorb popular culture. What does "preesh" mean?

WT: Oh, it's a hippie thing they say in California. Instead of "I appreciate it," they say, "Preesh, dude."

SF: But you live in Brooklyn and North Carolina. Do you pick these things up on the Internet?

WT: I try really hard to get away from it as much as I can, but I'm just as bad as anybody else with the Internet. Left to my own devices, I'd spend all day looking at shoes. I kind of feel bad for our generation. I grew up wordprocessing, being able to cut and paste. It seems ridiculous that we should be writing on what's basically a television. Why are we using that machine to create literature? I'm waiting for somebody to develop a really good word processor with no web capability. Soon, the culture is going to realize we don't always have to be looking at dog collars on eBay seventeen hours a day. We're going to be more selective about it. We know it trains us to read in a different, worse way. Reading on the Internet is basically a gist harvest. Fiction doesn't have anything to do with any sort of gist. When we're try-

THE IOWA REVIEW 
ing to come up with sentences that matter, and characters that matter, and things that are important, and words that must be read carefully-that's the opposite kind of reading from what the Internet trains us to do.

SF: You're so witty and your stories rely on the play of verbal pyrotechnics, but at the same time there's a real sweetness to them, a strong core and heart. Do you ever worry that the humor and language will overshadow what matters in your stories?

WT: It's all in the balance. Fiction is born of rival impulses. When I write a funny story, it can feel cowardly and lame. So then I write a draft where I amp up the emotional stakes. I write a really earnest story. But then it can feel not-so-cool. So in the next draft, I focus on paring down the sentimentality but ratcheting up the pyrotechnic stuff with the language. But then that will feel like cheating. So I go back and simplify it and make sure there aren't too many metaphors and that any time I'm pulling a language trick, it actually is in service of the story.

I was in an art gallery the other day with a friend of mine who is a painter, and we saw a painting that I thought was pretty cool. She said, "No, that sucks." She said the artist didn't build up the canvas. You can see whether somebody has gone at a visual or aesthetic problem a bunch of different ways. Each of those attacks leaves its trace on a piece of work. On a sentence level I'm not as brainy about it. I think about thread count. Anytime I read something that doesn't have a tight weave, I stop reading.

SF: Did you do that in the story "Everything Ravaged, Everything Burned"?

WT: That story actually began as a joke. In it, these wisecracking Viking dudes go on a siege but they're not so keen on it. In graduate school, I'd been trying really hard to write sincere, meaningful fiction. Then I thought I'd take a Raymond Carver set of dudes and put them in a Viking siege, and that'd be funny. But as I was writing the story it began to accumulate its own emotional heft. And the characters, even though I intended to do just the worst kind of Hagar the Horrible, they insisted that I care about them. It ended up being the most sentimental, heartfelt story in the book, which I get away with because it's full of gruesome slaughter and hideousness. If there 
are enough eviscerations, you can afford a couple of paragraphs of somebody worrying about his family.

SF: There's a lot of specific knowledge in your stories-how to dress a moose or build a house. How do you research?

WT: I do most of that on the Internet.

SF: Did anyone ever advise you not to focus on short stories and write a novel instead?

WT: I just got that e-mail from my agent yesterday, as a matter of fact. I'm under contract for one, and I am trying to write it. But I'm going to take my time with it. There's a real risk with second books. You get some attention for your first book and you think that book got attention because you're a great writer and not because you spent seven or eight or ten years writing a great book. So you crank out another one in a year, and it gets savaged. I don't want to write a terrible book.

SF: Do you think of yourself as a short story writer?

WT: The collection is an apprenticeship of the short story. The short story was a more effective laboratory than the novel. It was a good way to try different approaches. It seems strange to me that the story collection has gotten reviewed as a coherent volume, because for me it was a piecemeal thing. I was generally really unhappy with the stories as I was writing them. With each story, I tried to write something that sucked differently from the previous one.

SF: Are you patient?

WT: I'm not that patient. But my disgust with the work was sincere. I had a decent enough publication record fairly early on where I had a couple of agents saying, "Yeah, we can probably sell this book now." But the process of revision was what interested me. When I first started writing, I could write a short story in ten days or two weeks, so I thought that's what a short story is: a funny or interesting anecdote on which you hang literary curtains and 
doilies and stuff. But the process changed so much for me. It became about waiting for the characters' lungs to develop, for them to become real for me. Revision was humbling. I got to see the primitiveness and simplicity of the early drafts, but I also got to see that there was something useful there that I shouldn't destroy if I could avoid it.

SF: How do you incorporate metaphors into your stories?

WT: Revision is often the process of subtracting the metaphors. I can go a little crazy with them. In my early stories, I'd have six metaphors per paragraph. I had to think about what I was really doing with a metaphor. Is it just showing off to say that something is like something else? How often does it really bring either pleasure to the reader or illumination to the thing that you are trying to illuminate? It's easy to get into hot-air territory with metaphors. It's a tambourine to bang sparingly.

SF: Were you surprised by the critical reception of the book?

WT: I don't feel like I am doing anything terribly fancy or abstract with my stories. It's a pretty simple project. I want to tell stories with characters that are believable. I want to tell stories that are funny without being silly, stories that are unsentimental but that also say something about what it is to be a human being. And I want to do it in language that is careful and satisfying and delivers some satisfactions on the sentence level. For me, that's it.

SF: Who are the writers you turn to?

WT: My tastes in short fiction are awfully traditional: Cheever, Richard Yates, Flannery O'Connor.

SF: How did you know you wanted to be a writer?

WT: I think I was weirdly quite young. I had a strange appetite for language. In first grade, I wrote a couple of plays. One was a combined moral lesson on pet care and tooth decay. In college, I wanted to major in literature, but I somehow convinced myself that that would be a bourgeois and decadent thing to study. I majored in sociology and anthropology and thought I was 
going to get a PhD, but I just despised what the academics were doing with language. It was often an exercise in obscuring rather than actually revealing anything about people. For me, literary writing was a better way to get out of it.

SF: Is your family funny?

WT: My family is very funny. They're linguistically agile people who tend to say things that they don't even realize are funny. My father was telling me about a run-in he had with a policeman many years ago. He was telling it as a painful memory. The policemen was yelling, "Do you want me to haul you downtown and lock you up?" My dad said, "Well, that wouldn't be my first choice." That kind of courtly delivery is hilarious to me. I don't know if they're a humor-family; they're bright people who like to laugh at things.

SF: Do you try to write combative dialogue?

WT: No, but it's rare that we actually communicate when we have conversations. If I were to look at the transcripts of my conversations with my parents or ex-girlfriends, I wouldn't see a conversation; I'd just see two parallel monologues where people are saying what they want to get across and not really listening. If you have dialogue in which one character is simply responding to the other, it just sounds fake.

Part of it stems from the desire to have legible conflict in the stories without having to explain it in the narrative sections. Conflict is difficult to dramatize without it tilting into hysteria. Having tiny swords flashing in quiet conversation is a better way to get at it.

SF: Do you think in terms of a traditional plot structure?

WT: Not really. I can't remember who said this, but in a short story something should happen but not too much. In short stories, the trick is often to try to find a way for fewer things to happen. There might be six or seven dramatic ideas or sources of friction that will constitute the story in a rich way, but then it's a matter of paring them down. Six or seven dramatic scenes diffuse a story. You can really only manage one or two. 
Cheever was very good with this. In "Goodbye, My Brother," the fuse ignites and then you have that final incident of violence at the end. It's really fantastic.

SF: In "Wild America," you echo the Cheever line, "What can you do with a man like that?" from "Goodbye, My Brother."

WT: Oh, yes- "what would you do with a girl like that." I actually remember thinking of Joyce when I was writing that line: "Oh, impossible person." I'm sure some Cheever slipped across the membrane. I wouldn't be surprised.

SF: Do you worry about borrowing or stealing?

WT: People are extremely uptight about anything that might smack of excessive influence or plagiarism. At the same time, books are really made out of other books, and other writers teach us how to write. It's very hard to avoid the occasional sequence of language or word that happens to have certain associations. It's impossible to pry every word or line free and make it your own. With Independence Day, Richard Ford said he was rewriting The Moviegoer, or at least revisiting it. There are a few lines in there where the exact line turns up in a new way. For me, Ford's not being unoriginal. He's digesting that book, and it's coming out in a new form.

SF: Did you ever try writing "experimental" fiction?

WT: No, I don't think experimental fiction is necessarily more distinctive or more liberated from tradition than writing in a realistic mode.

SF: Allan Gurganus is teaching a course on Chekhov's short fiction here at Iowa this semester. He's pairing Chekhov's stories with their contemporary counterparts. He paired "Retreat" with "Gooseberries."

WT: I haven't read "Gooseberries" in fifteen years. I have yet to really crack the Chekhovian code. I remember reading Chekhov in high school. I would get to the end of the story and think, that's it? That's the story? A guy worries about his relationship with his wife and then goes outside and picks up a chicken? It's a strange Russian thing. The moment gets a different sort of 
treatment. Chekhov is such an elegant writer and is able to do such beautiful things with minor moments, but for me it was really Carver who took Chekov's approach and made it make sense to me for the first time. Carver was able to take a tiny, unattended moment and show you how it could cause a life to rock on its axis. For me, he was the first to make the quiet moment smack a big gong.

SF: How do you decide the location for despair or anxiety in your stories?

WT: It has to be a moment that would endure in the long-term memory of the characters, an afternoon or day or month that twenty years down the line they would be able to recall. That may be why humiliation figures so largely in my stories, because there's no emotional event that you can relive with painful granularity like humiliation. You can recall joy or anger or love, but when you think back on when you came to school with your fly down, you feel that hot burning shame in your chest just as you did when you first experienced it.

SF: What is the most difficult part about success?

WT: The public part. It's a strange thing. Even the minor success of this book has been a distraction. Last year there was a book tour and then I agreed to go to a lot of literary festivals because I was amazed that anybody would fly me to Australia for a week and put me up in a fancy hotel. I said yes to enough of those things that it really derailed my writing. I was getting on a plane about every ten days. I didn't read any reviews, and I wouldn't look at anything that anybody said online about the book because, it seems, once you let people tell you what kind of artist you are, there is a real risk that then, when you sit down to work, you try to be that artist. 